\title{
ANALISIS KECELAKAAN KERJA DI BAGIAN PRODUKSI PT. YYY LAMPUNG PLANT DENGAN METODE FMEA DAN FTA
}

\author{
Muhammad Indra Jaya ${ }^{1}$, Susanti Sundari ${ }^{1 *}$, Suharto ${ }^{1}$ \\ ${ }^{1}$ Progam Studi Teknik Industri Fakultas Teknik \\ Universitas Tulang Bawang Lampung \\ Jl. Gajah Mada No. 34 Kotabaru Bandar Lampung \\ *Penulis Korespondensi: susantisundari09@gmail.com
}

\begin{abstract}
This research discusses the Analysis of Work Accidents with FMEA and FTA Methods in the Production Section of PT. YYY Lampung Plant. The purpose of this study is to determine the risk factors that cause work accidents, types of work accidents, work accident rates, and the root causes of work accidents in the production department. This research is a quantitative descriptive study with data analysis using FMEA and FTA methods. The data collection method used primary data in the form of work accident data and secondary data in the form of questionnaires to 50 employees. The results showed that the risk factors for work accidents exist in 5 production process activities, namely in the process of selecting raw materials, cutting, weighing, product formation, and finishing. The types of work accidents that often occur are pinched, crushed, sliced, and hit the body, while the highest accident rate with an RPN value of 350.6 is pinched in the finishing process. The results of this RPN value indicate that the number of work accidents is a very high number (>200). And the root cause of work accidents based on Fault Tree Analysis on work accidents in the form of being squeezed with a RPN value of 350.6 caused by lack of concentration, employees not feeling well, sleepy workers, and limited (narrow) work space. Based on these data, it can be concluded that the level of work accidents should receive special attention.
\end{abstract}

Keywords: FMEA, FTA, Production, Work Accident

\section{Pendahuluan}

Keselamatan dan kesehatan kerja merupakan isu kontroversial yang paling signifikan dalam mensukseskan pengembangan industri (Jilca dan Kitaw, 2017). Seiring dengan berkembangnya teknologi yang digunakan, terjadi peningkatan potensi bahaya kecelakaan dan penyakit akibat kerja. Hal ini menjadi prioritas setiap perusahaan untuk menjadikan program Keselamatan dan Kesehatan Kerja (K3) sebagai acuan dasar seluruh perusahaan dalam menunjang keberhasilan suatu perusahaan. K3 adalah aspek penting dalam meningkatkan kesejahteraan dan produktivitas karyawan. K3 memperhatikan mengenai masalah manajemen resiko di tempat kerja yang mana resiko tersebut dapat berakhir dengan sebuah kecelakaan, luka-luka, atau kesehatan yang buruk (Chris Rowley \& Keith Jackson, 2012). Sebelum berfokus pada peningkatan keselamatan dan kesehatan kerja, perlu menjadi perhatian oleh suatu perusahaan yaitu angka kecelakaan kerja dan penyebab kecelakaan kerja tersebut dapat terjadi.

PT. YYY Lampung Plant merupakan suatu perusahaan yang berkecimpung pada bidang pengolahan hasil laut (rajungan) dan berlokasi di Bandar Lampung. Beberapa produk makanan olahan yang diproduksi PT. YYY yaitu crab cake dan dimsum. Dalam 
kegiatan produksinya tidak terlepas dari berbagai macam kecelakaan kerja yang disebabkan oleh beberapa faktor, seperti lingkungan kerja, mesin, dan manusia. Angka kecelakaan kerja 3 tahun terakhir menunjukkan kenaikan yang signifikan sehingga perlu mendapat perhatian khusus karena akan berpengaruh kepada produktivitas kerja dan produktivitas produksi pada perusahaan tersebut. Jika tingkat keselamatan kerja SDM tinggi, kecelakaan yang menyebabkan sakit, cacat, dan kematian dapat ditekan seminimun mungkin. Begitu pula bila tingkat keselamatan kerja rendah, maka akan berpengaruh buruk terhadap kesehatan sehingga akan berakibat pada produktivitas yang menurun.

Failure Mode and Effect Analysis (FMEA) merupakan suatu metode yang digunakan untuk mengidentifikasi bentuk kegagalan yang mungkin menyebabkan setiap kegagalan fungsi dan untuk memastikan pengaruh kegagalan berhubungan dengan setiap bentuk kegagalan (Mourby, 1997). Analisis FMEA memfokuskan pada penyebab kerusakan dan mekanisme terjadinya kerusakan dengan memberikan gambaran mengenai tingkat kerawanan sehingga dapat menentukan skala prioritas atau nilai Risk Priority Number (RPN). Menurut Xu et al (2002) dan Yeh dan Hsieh (2007) yang dikutip oleh Apriyan J. et al (2017), beberapa kelemahan FMEA yaitu FMEA bersifat subjektif dan kualitatif sehingga tidak jelas dalam bahasa ilmiah, parameter keparahan, kejadian, dan deteksi biasanya memiliki kepentingan yang berbeda, dan nilai RPN yang dihasilkan dari perkalian S, O, dan D sering sama, padahal sebenarnya mempresentasikan nilai resiko yang berbeda. Untuk itu metode ini digabungkan dengan metode lain dalam bidang keselamatan kerja yaitu Fault Tree Analisys (FTA), dengan menggunakan pohon kesalahan yang secara sederhana dapat diuraikan sebagai suatu teknik untuk melakukan analisis, khususnya untuk analisis mengenai $\mathrm{K} 3$.

Tujuan dari penelitian ini yaitu untuk mengetahui faktor-faktor resiko yang menyebabkan terjadinya kecelakaan kerja, jenis kecelakaan kerja yang sering terjadi, mengetahui tingkat kecelakaan kerja dan mengidentifikasi akar penyebab kecelakaan kerja di bagian produksi PT. YYY Lampung Plant.

\section{Metodologi Penelitian}

Jenis penelitian ini merupakan penelitian deskriptif yang tujuannya untuk memperoleh gambaran penelitian terkait analisis K3 di PT. YYY Lampung Plant. Metode yang digunakan adalah metode FMEA dan FTA.

Metode analisis data yang digunakan adalah metode analisis kuantitatif deskriptif, yaitu analisis yang berdasarkan pengukuran hasil usaha keselamatan kerja dari kejadian kecelakaan kerja. Untuk kejadian kecelakaan ringan analisa yang dilakukan berdasarkan datadata yang ada diperusahaan.

1. Failure Mode and Effect Analisis (FMEA) merupakan teknik analisis risiko secara sirkulatif yang digunakan untuk mengindentifikasi bagaimana suatu peralatan, fasilitas/sistem dapat gagal serta akibat yang dapat ditimbulkannya. Hasil FMEA berupa rekomendasi untuk meningkatkan kehandalan tingkat keselamatan fasilitas, peralatan/sistem. FMEA merupakan metode yang tepat untuk dilakukan karena mengatur tingkat resiko kecelakaan kerja berdasarkan tiga parameter yaitu keparahan/ Severity $(\mathrm{S})$, kejadian/Occurance $(\mathrm{O})$, dan deteksi/Detection (D).

2. Suatu analisis pohon kesalahan (Fault Tree Analysis) diuraikan sebagai suatu teknik analisis, dimana kesalahan suatu sistem dianalisis dalam konteks operasi dan lingkungannya untuk menemukan semua cara yang dapat dipercaya dalam peristiwa yang tidak diinginkan dapat terjadi. FTA adalah suatu model grafis yang menyangkut berbagai paralel dan kombinasi percontohan kesalahankesalahan yang akan mengakibatkan kejadian dari 
peristiwa yang tidak diinginkan yang sudah didefinisikan sebelumnya. Untuk membangun FTA diperlukan langkah-langkah sebagai berikut:

a. Mendefinisikan kecelakaan

b. Mempelajari sistem dengan cara mengetahui spesifikasi peralatan, lingkungan kerja dan prosedur operasi.

c. Mengembangkan pohon kesalahan (Analisa Kualitatif).

d. Menghitung nilai frequency rate, severity rate, dan safe T-score (Analisa Kuantitatif)

e. Penarikan Kesimpulan

\section{Hasil dan Pembahasan}

Pada tabel 1 menunjukkan hasil penelitian, dimana jumlah kecelakaan kerja di PT. YYY Indonesia Lampung Plant pada tahun 2019, yaitu:

Tabel 1. Jumlah Kecelakaan Kerja Tahun 2019.

\begin{tabular}{|c|c|c|c|}
\hline No. & Jenis Kecelakaan Kerja & Resiko Kecelakaan & Jumlah Kecelakaan \\
\hline \multirow[t]{8}{*}{1.} & Pemilihan Bahan Baku & & \\
\hline & Tertimpa bahan baku & $\begin{array}{l}\text { Keselo/cidera pada bagian } \\
\text { badan }\end{array}$ & 2 \\
\hline & Terkilir & Keseleo & 1 \\
\hline & $\begin{array}{l}\text { Terpeleset akibat lokasi lantai } \\
\text { licin }\end{array}$ & Nyeri & 1 \\
\hline & Tangan terjepit kaleng & Cacat bagian ibu jari & 1 \\
\hline & Tangan lecet & Kulit tangan terkelupas & 1 \\
\hline & Badan terbentur & $\begin{array}{l}\text { Sakit dibagian perut dan } \\
\text { memar }\end{array}$ & 1 \\
\hline & & & 7 \\
\hline \multirow[t]{5}{*}{2.} & Proses Pemotongan & & \\
\hline & Teriris & Tangan luka & 3 \\
\hline & Mata pedih saat memotong & $\begin{array}{l}\text { Mata pedih dan } \\
\text { mengeluarkan air mata }\end{array}$ & 1 \\
\hline & Badan terbentur & $\begin{array}{l}\text { Sakit dibagian perut dan } \\
\text { memar }\end{array}$ & 1 \\
\hline & & & 5 \\
\hline \multirow[t]{4}{*}{3.} & Proses Penimbangan & & \\
\hline & Tersengat listrik timbangan & Pingsan & 1 \\
\hline & Tertimpa & Tangan memar & 1 \\
\hline & & & 2 \\
\hline \multirow[t]{5}{*}{4.} & Proses Pembuatan Produk & & \\
\hline & Terkilir & Keseleo & 1 \\
\hline & Bising karena suara mesin & Pendengaran terganggu & 1 \\
\hline & $\begin{array}{l}\text { Terkena minyak panas saat } \\
\text { proses penggorengan }\end{array}$ & $\begin{array}{l}\text { Tangan terciprat minyak } \\
\text { sehingga melepuh }\end{array}$ & 1 \\
\hline & & & 3 \\
\hline \multirow[t]{9}{*}{5.} & Proses Finishing & & \\
\hline & Terkena lem panas & Tangan melepuh & 1 \\
\hline & Terkena mesin tunnel & $\begin{array}{l}\text { Telapak tangan menempel } \\
\text { pada mesin }\end{array}$ & 1 \\
\hline & Terjepit & Tangan nyeri & 1 \\
\hline & Tertimpa & Memar dan nyeri & 1 \\
\hline & Tersandung & Nyeri & 1 \\
\hline & Terpeleset & Nyeri & 1 \\
\hline & & & 6 \\
\hline & & Total & 23 \\
\hline
\end{tabular}

Sumber: Data Penelitian 


\section{Analisis Data Berdasarkan Metode FMEA}

\section{Nilai Severity (S)}

Severity menunjukkan tingkat keseriusan akibat yang ditimbulkan. Skala yang digunakan pada penelitian ini berdasarkan standar Incident Severity Scale (Priest, 1996). Hasil penelitian terkait nilai severity dapat dilihat pada tabel 2 .

Tabel 2. Nilai Severity (S)

\begin{tabular}{llcc}
\hline No. & \multicolumn{1}{c}{ Jenis Kecelakaan Kerja } & Total & Nilai S \\
\hline 1. & Pemilihan Bahan Baku & 212 & 4,2 \\
& Tertimpa bahan baku & 192 & 3,8 \\
& Terkilir & 152 & 3,0 \\
& Terpeleset akibat lokasi lantai licin & 322 & 6,4 \\
& Tangan terjepit kaleng & 215 & 4,3 \\
& Tangan lecet & 171 & 3,4
\end{tabular}

2. Proses Pemotongan

Teriris

Mata pedih saat memotong

Badan terbentur

3. Proses Penimbangan

Tersengat listrik timbangan

Tertimpa

4. Proses Pembuatan Produk

Terkilir

Bising karena suara mesin

Terkena minyak panas saat proses penggorengan

\section{Proses Finishing}

Terkena lem panas

Terkena mesin tunnel

Terjepit

Tertimpa

Tersandung

Terpeleset 


\section{Nilai Occurrence $(O)$}

Hasil penelitian terkait nilai occurrence terdapat pada tabel.3

Tabel 3. Nilai Occurrence (O)

\begin{tabular}{|c|c|c|c|}
\hline No. & Jenis Kecelakaan Kerja & Total & Nilai O \\
\hline \multirow[t]{7}{*}{1.} & Pemilihan Bahan Baku & & \\
\hline & Tertimpa bahan baku & 250 & 5,0 \\
\hline & Terkilir & 270 & 5,4 \\
\hline & Terpeleset akibat lokasi lantai licin & 342 & 6,8 \\
\hline & Tangan terjepit kaleng & 252 & 5,0 \\
\hline & Tangan lecet & 332 & 6,6 \\
\hline & Badan terbentur & 212 & 4,2 \\
\hline \multirow[t]{4}{*}{2.} & Proses Pemotongan & & \\
\hline & Teriris & 398 & 7,9 \\
\hline & Mata pedih saat memotong & 418 & 8,3 \\
\hline & Badan terbentur & & 4,0 \\
\hline \multirow[t]{3}{*}{3.} & Proses Penimbangan & & \\
\hline & Tersengat listrik timbangan & 279 & 5,5 \\
\hline & Tertimpa & 259 & 5,1 \\
\hline \multirow[t]{4}{*}{4.} & Proses Pembuatan Produk & & \\
\hline & Terkilir & 301 & 6,0 \\
\hline & Bising karena suara mesin & 441 & 8,8 \\
\hline & $\begin{array}{l}\text { Terkena minyak panas saat proses } \\
\text { penggorengan }\end{array}$ & 380 & 7,6 \\
\hline \multirow[t]{7}{*}{5.} & Proses Finishing & & \\
\hline & Terkena lem panas & 318 & 6,3 \\
\hline & Terkena mesin tunnel & 332 & 6,6 \\
\hline & Terjepit & 346 & 6,9 \\
\hline & Tertimpa & 231 & 4,6 \\
\hline & Tersandung & 108 & 2,1 \\
\hline & Terpeleset & 400 & 8,0 \\
\hline
\end{tabular}

Sumber: Data Penelitian

\section{Nilai Detection (D)}

Hasil penelitian terkait nilai detection dapat dilihat pada tabel 4 .

Tabel 4. Nilai Detection (D)

\begin{tabular}{|c|c|c|c|}
\hline No. & Jenis Kecelakaan Kerja & Total & Nilai D \\
\hline \multirow[t]{7}{*}{1.} & Pemilihan Bahan Baku & & \\
\hline & Tertimpa bahan baku & 248 & 4,9 \\
\hline & Terkilir & 247 & 4,9 \\
\hline & Terpeleset akibat lokasi lantai licin & 219 & 4,3 \\
\hline & Tangan terjepit kaleng & 300 & 6,0 \\
\hline & Tangan lecet & 240 & 4,8 \\
\hline & Badan terbentur & 238 & 4,7 \\
\hline \multirow[t]{4}{*}{2.} & Proses Pemotongan & & \\
\hline & Teriris & 301 & 6,0 \\
\hline & Mata pedih saat memotong & 220 & 4,4 \\
\hline & Badan terbentur & 250 & 5,0 \\
\hline \multirow[t]{3}{*}{3.} & Proses Penimbangan & & \\
\hline & Tersengat listrik timbangan & 151 & 3,0 \\
\hline & Tertimpa & 270 & 5,4 \\
\hline
\end{tabular}


4. Proses Pembuatan Produk

$\begin{array}{lll}\text { Terkilir } & 220 & 4,4\end{array}$

$\begin{array}{lll}\text { Bising karena suara mesin } & 170 & 3,4\end{array}$

$\begin{array}{lr}\text { Terkena minyak panas saat proses } & 182 \\ \text { penggorengan } & 3,6\end{array}$

5. Proses Finishing

$\begin{array}{lll}\text { Terkena lem panas } & 190 & 3,8\end{array}$

Terkena mesin tunnel $\quad 351 \quad 7,0$

$\begin{array}{lll}\text { Terjepit } & 331 & 6,6\end{array}$

$\begin{array}{lll}\text { Tertimpa } & 253 & 5,0\end{array}$

$\begin{array}{lll}\text { Tersandung } & 287 & 5,7\end{array}$

$\begin{array}{lll}\text { Terpeleset } & 270 & 5,4\end{array}$

Sumber: Data Penelitian

4. Perhitungan Nilai Risk Priority Number (RPN)

Hasil analisis penelitian terkait nilai severity, occurrence, dan detection, didapatkan nilai RPN pada tabel 5.

Tabel 5. Nilai Risk Priority Number (RPN)

\begin{tabular}{|c|c|c|c|c|c|}
\hline No. & Jenis Kecelakaan Kerja & $\mathbf{S}$ & $\mathbf{O}$ & $\mathbf{D}$ & RPN \\
\hline \multirow[t]{7}{*}{1.} & Pemilihan Bahan Baku & & & & \\
\hline & Tertimpa bahan baku & 4,2 & 5,0 & 4,9 & 102,9 \\
\hline & Terkilir & 3,8 & 5,4 & 4,9 & 100,5 \\
\hline & Terpeleset akibat lokasi lantai licin & 3,0 & 6,8 & 4,3 & 87,7 \\
\hline & Tangan terjepit kaleng & 6,4 & 5,0 & 6,0 & 192 \\
\hline & Tangan lecet & 4,3 & 6,6 & 4,8 & 136,2 \\
\hline & Badan terbentur & 3,4 & 4,2 & 4,7 & 67,1 \\
\hline \multirow[t]{4}{*}{2.} & Proses Pemotongan & & & & \\
\hline & Teriris & 2,6 & 7,9 & 6,0 & 123,2 \\
\hline & Mata pedih saat memotong & 2,8 & 8,3 & 4,4 & 102,3 \\
\hline & Badan terbentur & 4,6 & 4,0 & 5,0 & 92 \\
\hline \multirow[t]{3}{*}{3.} & Proses Penimbangan & & & & \\
\hline & Tersengat listrik timbangan & 3,0 & 5,5 & 3,0 & 49,5 \\
\hline & Tertimpa & 4,5 & 5,1 & 5,4 & 123,9 \\
\hline \multirow[t]{4}{*}{4.} & Proses Pembuatan Produk & & & & \\
\hline & Terkilir & 4,4 & 6,0 & 4,4 & 116,2 \\
\hline & Bising karena suara mesin & 2,0 & 8,8 & 3,4 & 59,8 \\
\hline & $\begin{array}{l}\text { Terkena minyak panas saat proses } \\
\text { penggorengan }\end{array}$ & 3,9 & 7,6 & 3,6 & 106,7 \\
\hline \multirow[t]{7}{*}{5.} & Proses Finishing & & & & \\
\hline & Terkena lem panas & 3,3 & 6,3 & 3,8 & 79 \\
\hline & Terkena mesin tunnel & 5,7 & 6,6 & 7,0 & 263,3 \\
\hline & Terjepit & 7,7 & 6,9 & 6,6 & 350,6 \\
\hline & Tertimpa & 5,1 & 4,6 & 5,0 & 117,3 \\
\hline & Tersandung & 3,2 & 2,1 & 5,7 & 38,3 \\
\hline & Terpeleset & 3,2 & 8,0 & 5,4 & 138,2 \\
\hline
\end{tabular}

Sumber: Data Penelitian

\section{Analisis Data Berdasarkan Metode FTA}

Analisis yang dilakukan dengan metode Faulth Tree Analysis (FTA) ada 2 metode, yaitu:

1. Analisis FTA secara Kualitatif

Analisis FTA secara kualitatif merupakan suatu metode FTA dengan menggambarkan akar penyebab kecelakaan kerja dengan membuat pohon akar kesalahan. Berikut merupakan hasil dari penelitian yang dilakukan digambarkan dengan pohon kesalahan pada tiap proses produksi: 


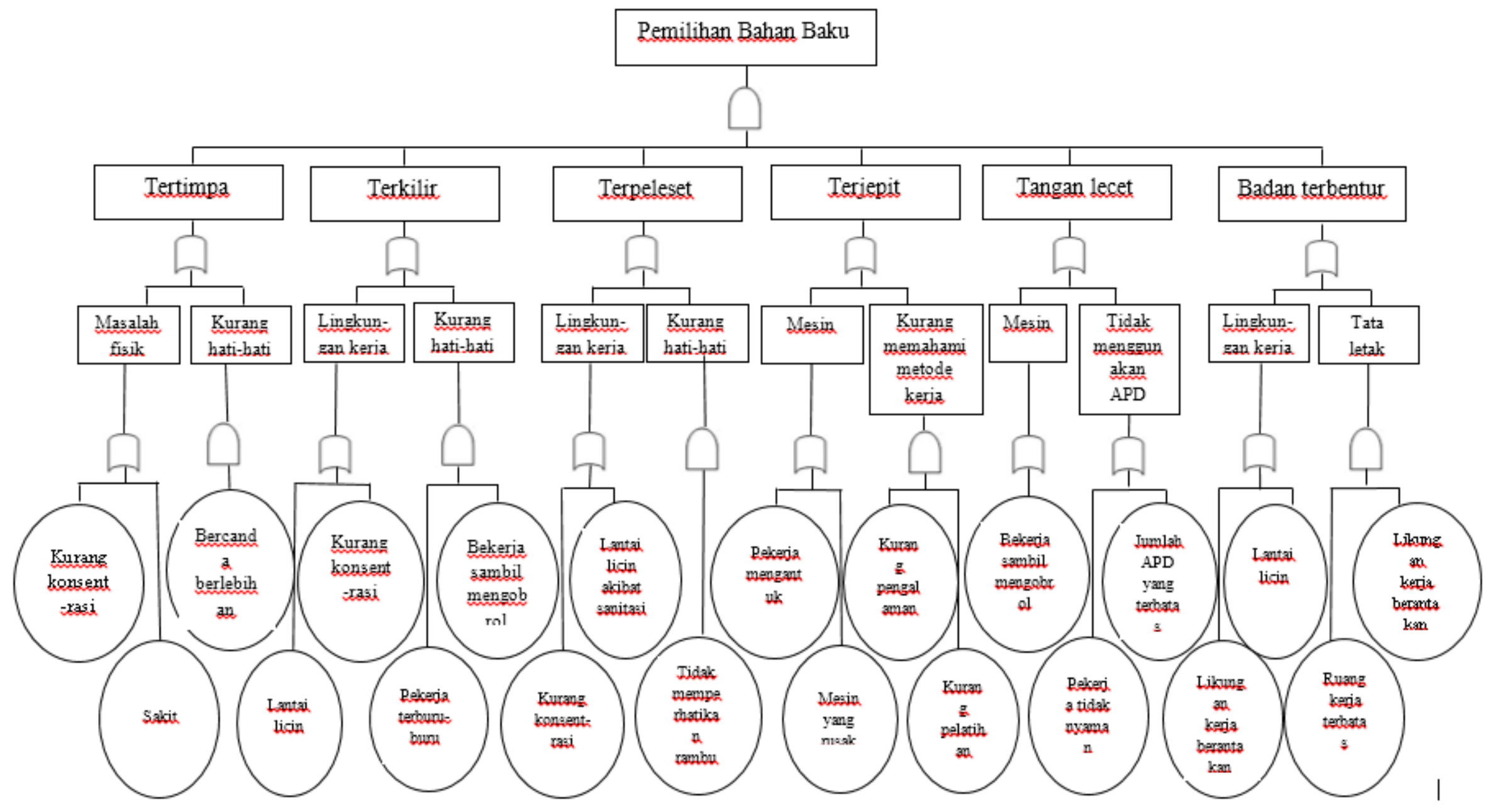

Gambar 1. Analisis Kualitatif FTA Pemilihan Bahan Baku 


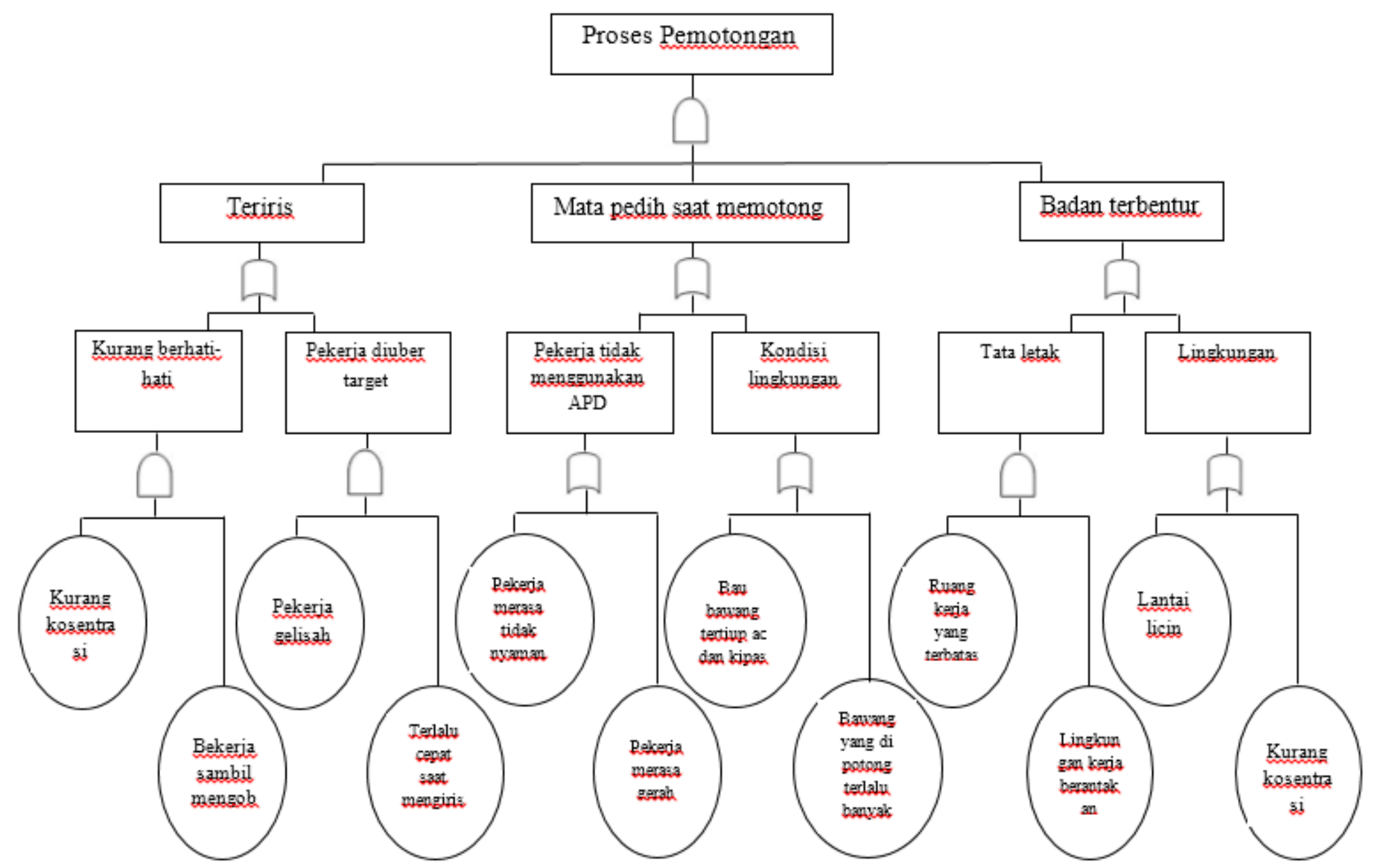

Gambar 2. Analisis Kualitatif FTA Pada Proses Pemotongan 


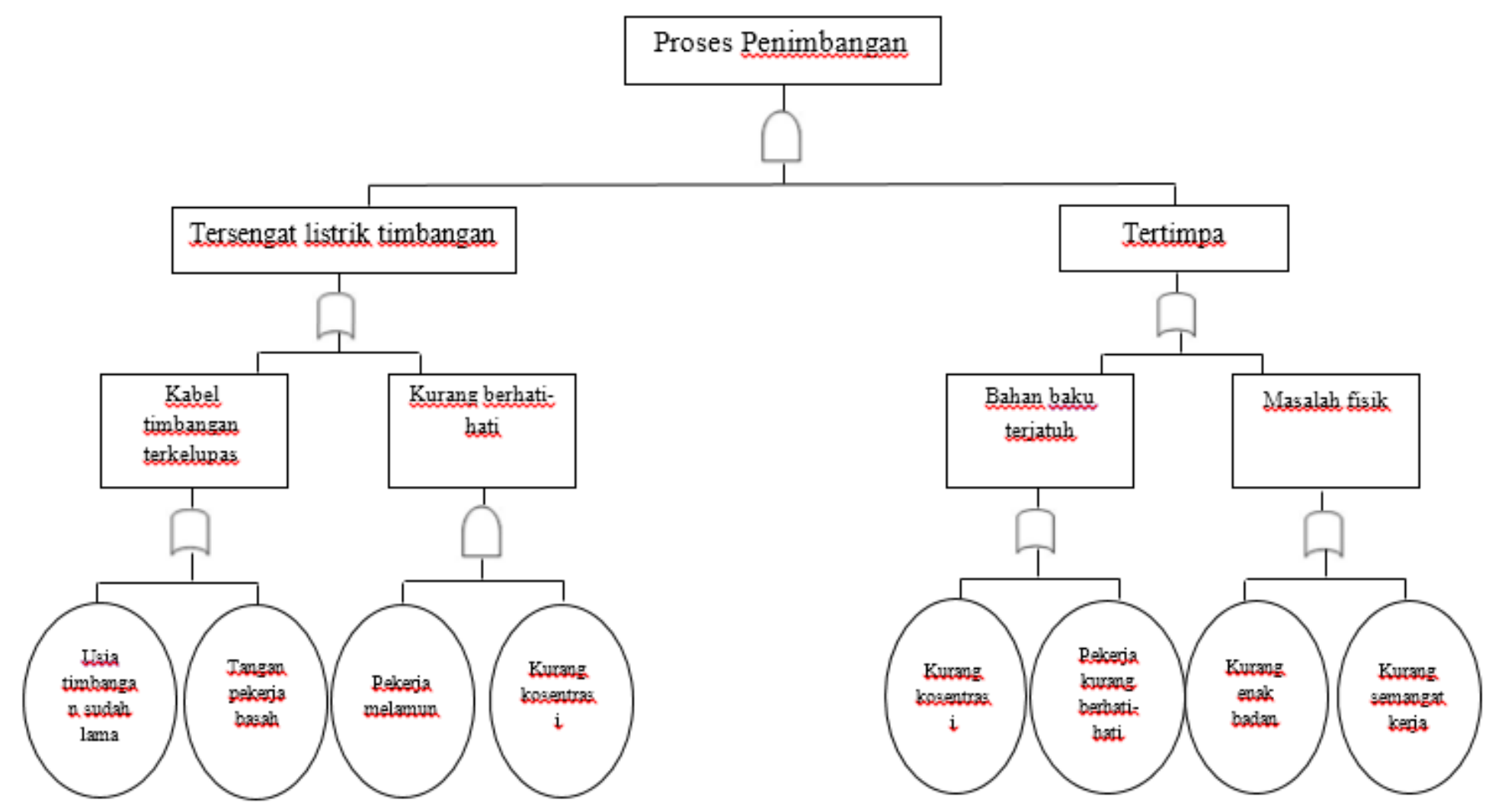

Gambar 3. Analisis Kualitatif FTA Proses Penimbangan 


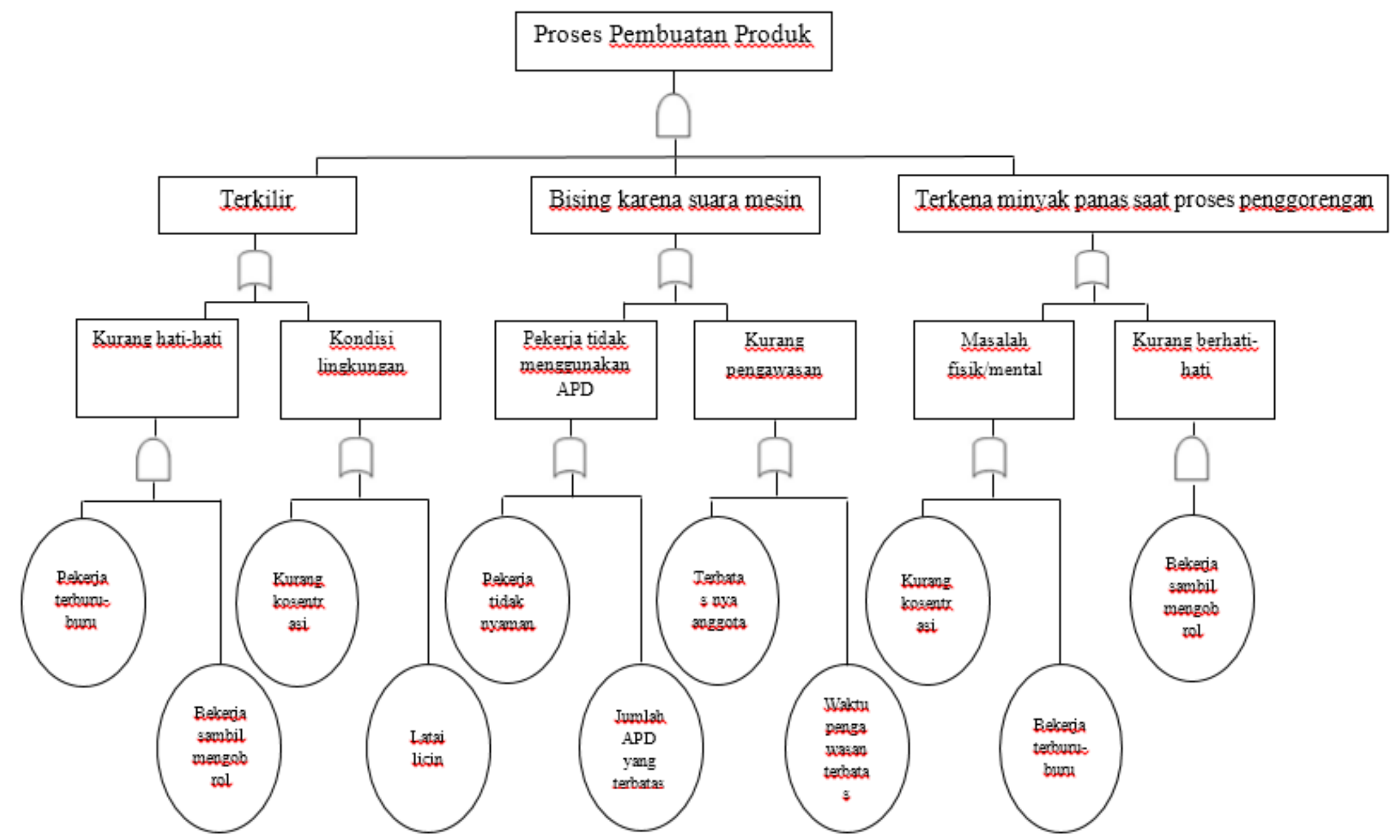

Gambar 4. Analisis Kualitatif FTA Pada Proses Pembuatan Produk 


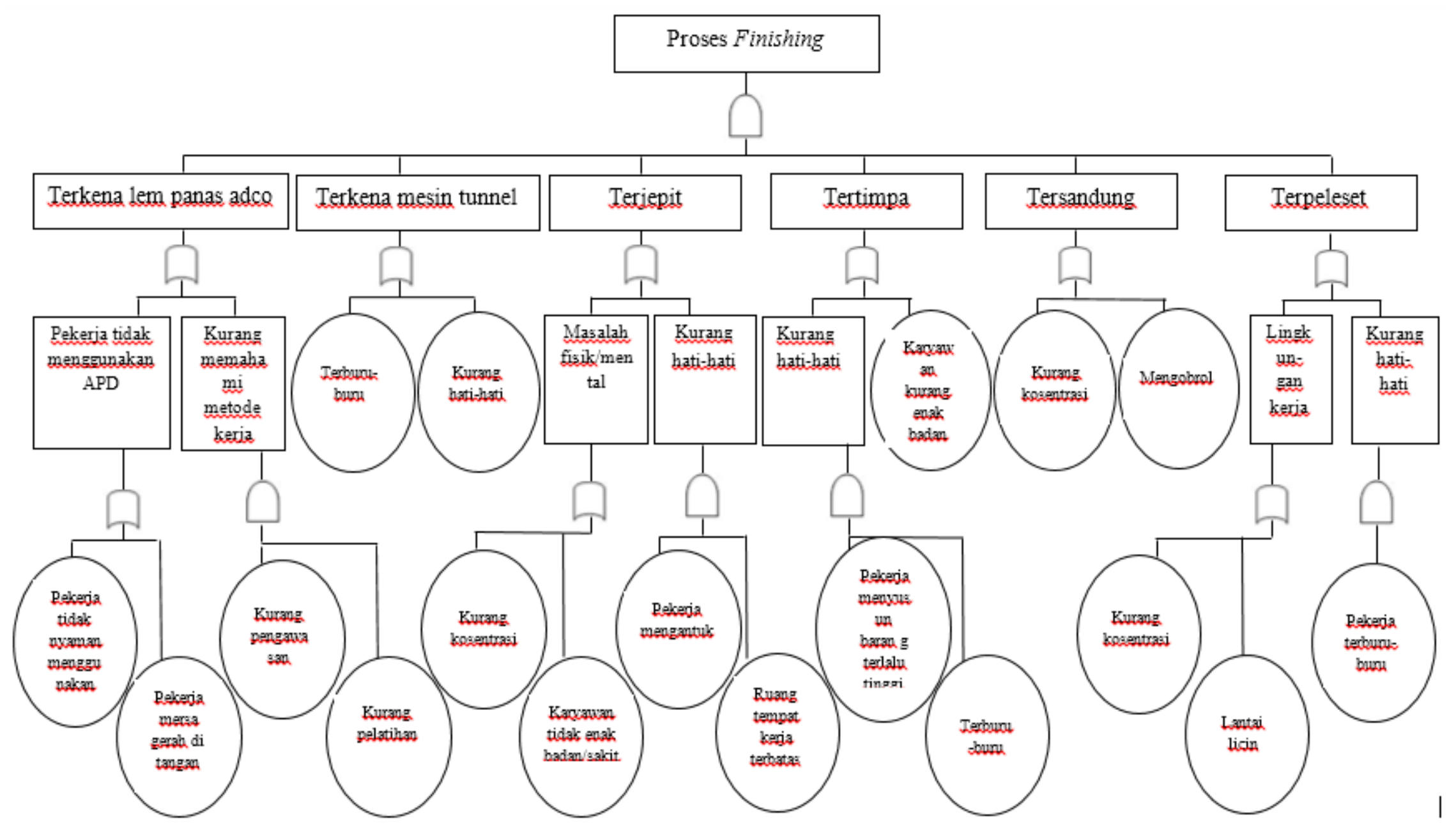

Gambar 5. Analisis Kualitatif FTA Proses Finishing 


\section{Analisis FTA secara Kuantitatif}

Analisis FTA secara kuantitatif adalah analisis yang dilakukan dengan menghitung frequency rate, severity rate, dan safe $T$ score.

\section{a. Pengukuran Frequency Rate}

Untuk mendapat tingkat frekuensi kecelakaan kerja, rumus yang digunakan adalah:

$\mathrm{F}=(\mathrm{n} \times 1.000 .000) / \mathrm{N}$

Keterangan:

F : Tingkat frekuensi kecelakaan

n : Jumlah kecelakaan yang terjadi

$\mathrm{N}$ : Jumlah jam kerja karyawan

Dari hasil analisis penelitian yang dilakukan dengan melihat data kecelakaan kerja dan data jumlah jam kerja karyawan PT. YYY pada tahun 2019 adalah sebanyak 247 hari (1.976 jam), maka didapatkan tingkat frekuensi kecelakaan kerja sebagai berikut :

$\mathrm{F}=(\mathrm{n} \times 1.000 .000) / \mathrm{N}$

$\mathrm{F}=(23 \times 1.000 .000) / 1.976$

$\mathrm{F}=(23.000 .000) / 1.976$

$\mathrm{F}=11,639$

Dari hasil perhitungan diatas maka tingkat frekuensi kejadian kecelakaan kerja di PT. YYY sebanyak 11,639 kali/tahun.

\section{b. Pengukuran Severity Rate}

Untuk mengukur pengaruh kecelakaan, perlu dihitung angka beratnya kecelakaan untuk sejuta jam kerja dari jumlah jam kerja karyawan.

$\mathrm{S}=(\mathrm{H} \times 1.000 .000) / \mathrm{N}$

Keterangan:

S : Tingkat severity

$\mathrm{H}$ : Jumlah total jam hilang karyawan

$\mathrm{N}$ : Jumlah jam kerja karyawan

Dari hasil analisis penelitian yang dilakukan dengan melihat data kecelakaan kerja PT. Phillips Seafood Indonesia Lampung Plant pada tahun 2019, maka didapatkan pengaruh kecelakaan kerja sebagai berikut :

$\mathrm{S}=(\mathrm{H} \times 1.000 .000) / \mathrm{N}$

$\mathrm{S}=(15 \times 1.000 .000) / 1.976$

$\mathrm{S}=(15.000 .000) / 1.976$

$\mathrm{S}=7,591$

Maka nilai severity yang didapatkan adalah 7,591. Nilai ini menunjukkan bahwa tingkat pengaruh atau dampak terjadinya kecelakaan kerja adalah berdampak besar pada individu sehingga tidak ikut lagi dalam aktivitas lebih dari 12 jam (dirawat di rumah sakit atau perlu beristirahat dirumah).

\section{c. Pengukuran Safe T-Score}

Nilai F1 diambil dari tahun sebelumnya dan nilai F2 adalah nilai pada tahun yang akan diukur. Pada pengukuran ini, rumus yang digunakan adalah sebagai berikut:

$$
\text { Safe } T \text {-Score }=\frac{F 2-F 1}{\sqrt{\frac{F 1}{N}}}
$$

Keterangan:

STS : Nilai T selamat

F1 : Tingkat frekuensi kecelakaan kerja masa lalu

F2 : Tingkat frekuensi kecelakaan kerja masa kini

$\mathrm{N}$ : Jumlah jam kerja karyawan

Dari hasil analisis penelitian yang dilakukan dengan melihat data kecelakaan kerja PT. YYY pada tahun 2019 jam kerja karyawan adalah sebanyak 247 hari (1.976 jam) dengan frekuensi sebanyak 11,639 dan tahun sebelumnya yaitu pada tahun 2016 sebanyak 246 hari kerja, tahun 2017 sebanyak 245 hari kerja, tahun 2018 sebanyak 245 hari kerja, maka total hari kerja pada tahun 2016, 2017, 2018 adalah sebanyak 736 hari dengan jam kerja sebanyak 5.888 jam dan jumlah kecelakaan kerja sebanyak 44 kejadian dengan hasil nilai frekuensi adalah 7,472 . Maka didapatkan pengaruh kecelakaan kerja sebagai berikut:

$$
\begin{aligned}
& \text { Safe T-Score }=\frac{11,639-7,472}{\sqrt{\frac{7,472}{1976}}} \\
& \text { Safe T-Score }=\frac{\mathbf{4 , 1 6 7}}{1,944} \\
& \text { Safe T-Score }=2,143
\end{aligned}
$$

Maka nilai $\mathrm{T}$ selamat dari perhitungan diatas adalah 2,143. Sehingga dari hasil perhitungan tersebut dapat dilihat bahwa angka kejadian kecelakaan kerja di PT. YYY menurun sebanyak 2,143 kali/tahun. 


\section{Kesimpulan}

Kesimpulan dari penelitian ini:

1.Faktor-faktor resiko yang menyebabkan terjadinya kecelakaan kerja dan jenis kecelakaan kerja yang ditemukan di bagian produksi PT. YYY adalah pada proses pemilihan bahan baku dengan resiko kerja berupa terkilir, cidera pada bagian badan, nyeri, kulit tangan terkelupas, cacat bagian ibu jari, dan sakit dibagian perut karena ruang kerja terbatas (sempit) serta memar, pada proses pemotongan dengan resiko kerja berupa tangan terluka, memar dan mata terasa pedih, pada proses penimbangan dengan resiko kerja berupa pingsan karena tersetrum (kondisi karyawan lemah) dan memar akibat tertimpa bahan adonan., pada proses pembuatan produk dengan resiko kerja berupa keseleo dalam mencetak produk, pendengaran terganggu kerena bising dan melepuh karena terciprat minyak penggorengan dan pada proses finishing dengan resiko berupa telapak tangan menempel pada mesin tunnel, tangan nyeri dan memar, kemudian tangan melepuh karena terkena lem panas pada mesin adco.

2. Tingkat kecelakaan kerja di bagian produksi PT. YYY yang memiliki nilai severity $(\mathrm{S})$ paling tinggi yaitu 7,7 terdapat pada proses finishing yaitu tangan terjepit Master Carton (MC) saat menyusun barang.

3. Akar penyebab kecelakaan kerja yang paling dominan berdasarkan analisis Fault Tree Analysis (FTA) di bagian produksi PT. YYY untuk kecelakaan kerja berupa terjepit dengan nilai RPN 350,6 yang disebabkan oleh kurangnya konsentrasi, karyawan tidak enak badan/sakit, pekerja mengantuk, dan ruang tempat kerja terbatas.

4. Disarankan untuk PT. YYY dalam upaya Kesehatan dan Keselamatan Kerja (K3) terutama pengendalian kecelakaan kerja agar memperbaiki tata letak ruangan produksi sehingga meminimalisir kejadian kecelakaan kerja, menyediakan APD (alat Pelindung Diri) berupa face shield, ear plug, sarung tangan yang tahan panas dan dingin, selalu mengecek kondisi timbangan serta kabel (pengecekan berkala) untuk meminimalisir kecelakaan kerja karena tersetrum.

\section{Daftar Pustaka}

Assauri. 1999. Manajemen Produksi dan Operasi, Edisi Revisi, Lembaga Penerbit Fakultas Ekonomi. Jakarta : Universitas Indonesia, dalam Panji D, dkk (April 2006) Tentang Pengaruh Faktor Keselamatan dan Kesehatan Kerja Terhadap Produktivitas Kerja Karyawan di PT. Gatra Mapan I, Malang.

Ahyari, Agus. 2002. Manajemen Produksi Perencanaan Sistem Produksi Buku 1, Edisi Keempat. Yogyakarta : BFFE UGM, dalam Tri Oki P dan Wagiran tentang Penerapan Keselamatan dan Kesehatan Kerja Pada Praktik Membubut.

Asyar, M.B. 2009. Analisis Sistem Manajemen Kesehatan dan Keselamatan Kerja Pada Bagian Produksi PT. Industri Kapal Indonesia (Persero) Makassar. Makassar: Universitas Islam Makassar.

Apriyan, J. et al .2017. Analisis Risiko Kecelakaan Kerja Pada Proyek Bangunan Gedung Dengan Metode FMEA. Yogyakarta: Universitas Atma Jaya

Anwar, dkk. 2019. Analisis Kesehatan dan Keselamatan Kerja Berdasarkan Metode Fault Tree Analysis pada Area Packing Semen PT. Lafarge Cement Lhokseumawe-Indonesia. Jornal Sistem Teknik Industri (JSTI) Vol. 21(1).

Budiono, A.M. 1992. Bunga Rampai Hiperkes dan Keselamatan Kerja. Jakarta : PT. Tri Tunggal Tata Fajar.

Busyairi M, dkk. 2014. Pengaruh Keselamatan Kerja dan Kesehatan Kerja Terhadap Produktivitas Kerja Karyawan. Jurnal Teknik 
Industri 13(2). 112-124.

Bpjs Ketenagakerjaan. 2018. Data Kecelakaan Kerja Indonesia Tahun 2018. Jakarta : BPJS. http :// www. bpjsketenagakerjaan.go.id. Diakses pada 2 Oktober pukul 14.00 WIB

Chris Rowley \& Keith Jackson. 2012. Humant Resources Development :The Key Concept. Published in the USA and Canada by Routledge. New York, dalam Kurniawan F dan Bole AG (2019) tentang Studi Kasus Pelaksanaan K3 Konstruksi Jembatan di Sumba.

Fifin Dwi dan I Wayan. 2017. Analisis Prioritas Kecelakaan Kerja dengan Metode Failure Mode and Effect Analysis di PT. PAL Indonesia (Persero). Surakarta : Universitas Sebelas Maret.

Jilca, K., Kitaw, D. 2017. Industrial Occupational Safety and Health Innovation for Sustainable Develoment Engeneering Science and Teknology, an International Journal, Vol 20,372-380 dalam Jurnal Rina S, dkk (2019) tentang Evaluasi Keselamatan dan Kesehatan Kerja Pada Praktik Perancangan Teknik Industri II Menggunakan Metode Job Safety Analysis.

Mourby, J. 1997. Reliability Centered Maintenance. New York : Industrial Press Inc. 2nd edition, dalam Rifai MP, Sriyanto: Analisis Kecelakaan Kerja dengan Metode FMEA.

Nementh, Christopher P,. 2004. Human Factors Methods for Design Making Systems Human-Centered, 1st edn. CRS Press : New York, Washington D.C.

National Incident Database Report, 2011, New Zealand Mountain Safety Council, New Zealand.

Peraturan Menteri Tenaga Kerja dan Transmigrasi. 2010. PER.08/MEN/VII/2010 Tentang Alat Pelindung Diri. Jakarta : Permenaker RI.

Peraturan Menteri Tenaga Kerja. 2018. Permenaker Nomor 5 tahun 2018 tentang Kesehatan dan Keselamatan Kerja Lingkungan Kerja. Jakarta : Permenaker RI.

Wisudawati YP, Abdul RT (2014) tentang Hubungan Antara Stres
Kerja dengan Tingkat

Produktivitas Tenaga Kerja di CV."X".

Systems and Reliability Reseach Office. 1981. Fault Tree Analysis Handbook. US : Nuclear Regulatory Commission.

Summa'mur, P. K. 1987. Keselamatan dan Pencegahan Kecelakaan. Cetakan Pertama. Jakarta : PT. Toko Gunung Agung, dalam Arifianto F dkk (2018) Evaluasi Penerapan K3 Proyek Upgrading Tangki Timbun 61 dengan Pendekatan FTA.

Summa'mur. 1996. Hygiene Perusahaan dan Keselamatan Kerja. Cetakan Kedua Hlm. 405-411. Jakarta : PT. Toko Gunung Agung, dalam Nuswantoro B, dkk: Pengaruh K3 Terhadap Produktivitas Kerja Karyawan dengan Menggunakan Structural Equation Model, Hlm. 6 (1105). Vol.2 No.5.

Sayuti, A.J. 2013. Manajemen Kantor Praktis. Bandung : Alfabeta, dalam Kurniawan F dan Bole AG (2019) tentang Studi Kasus Pelaksanaan K3 Konstruksi Jembatan di Sumba.

U.S Nuclear Regulatory Commission. 1981. Fault Tree Handbook. Washington, DC : U.S. Nuclear Regulatory Commission.

Wang, Y. M, Chin. K.S, Poon G.K.K, \& Yang J.B. 2009. Risk Evaluation in Failure Mode and Effect Analysis Using Fuzzyweighted Geometric Mean, Expert Systems with Applications 36 (2009) 1995-1207, Science Direct, dalam Haryanto, Metode FMEA dan FTA untuk Mengidentifikasi Potensi dan Penyebab Kecelakaan Kerja Pada Proyek Gedung 